Turkish Online Journal of Qualitative Inquiry (TOJQI)

Volume 12, Issue 2, April 2021: 357-376

DOI: $10.17569 /$ tojqi.847181

Research Article

\title{
A Contrastive Study on the Generic Structure and Socio-pragmatic Proclivities in Acknowledgements ${ }^{1}$
}

Tuğba Elif Toprak Y1ldız ${ }^{2}$, Yasemin Aksoyalp ${ }^{3}$

\begin{abstract}
The present study aimed to investigate the rhetorical organization of acknowledgements accompanying Doctor of Philosophy $(\mathrm{PhD})$ dissertations written in English by native speakers of English and Turkish, and gain insights into the underlying socio-pragmatic proclivities. To this end, the macro-textual analysis of $136 \mathrm{PhD}$ dissertations was conducted in light of Hyland and Tse's (2004) coding scheme. The findings revealed that more than half of $\mathrm{PhD}$ dissertation acknowledgements in both corpora consisted of only thanking move while the most commonly used step was thanking for academic assistance, followed by thanking for moral support. Moreover, the findings of the study also revealed that the acknowledgement section in $\mathrm{PhD}$ dissertations goes beyond being merely a part of a given dissertation and reflects social and cultural characteristics as well. The findings were discussed, and the implications were made.
\end{abstract}

Keywords: Acknowledgements, thanking, PhD dissertations, academic discourse, sociopragmatic variation

\footnotetext{
${ }^{1}$ Ethical committee permission is not required in this research since the data were gathered through document analysis.

${ }^{2}$ Assistant Professor, Izmir Democracy University, Faculty of Science and Letters, Department of English Language and Literature, Izmir, Turkey. E-mail: tugbaeliftoprak@gmail.com, ORCID ID: 0000-0003-0341229X

${ }^{3}$ Lecturer, Turkish-German University, School of Foreign Languages, Istanbul, Turkey. E-mail: aksoyalp@tau.edu.tr, ORCID ID: 0000-0002-7261-7064

Received: 05.01.2021, Accepted: 24.02.2021
} 


\title{
Doktora Tezi Teşekkür Bölümlerinin Organizasyonel Yapısı ve Sosyo-pragmatik Eğilimler Üzerine Karşılaştırmalı Bir Çalışma
}

\begin{abstract}
Öz
Bu çalışma, anadili İngilizce ve Türkçe olan araştırmacılar tarafından İngilizce olarak yazılan doktora tezlerinin teşekkür bölümünün retorik organizasyonunu incelemeyi ve mevcut organizasyona sebep olabilecek sosyo-pragmatik eğilimleri anlamayı amaçlamaktadır. $\mathrm{Bu}$ amaçla, bu nitel araştırmada, 136 doktora tezinin makro-metin analizi, Hyland ve Tse'nin (2004) geliştirdiği kodlama şeması 1şığında gerçekleştirildi. Bulgular, her iki bütüncedeki doktora tezlerinin yarısından fazlasının sadece teşekkür etme altsözcesinden oluştuğunu, en sık kullanılan yapıların ise akademik yardım için teşekkür etme ve manevi destek için teşekkür etme olduğunu ortaya koydu. Ayrıca, incelenen teşekkür bölümlerinde Hyland ve Tse'de (2004) bulunmayan iki farklı adıma rastlanmıştır. Genel olarak, çalışmanın bulguları, doktora tezlerinde yer alan teşekkür bölümünün bir tezin parçası olmanın ötesinde çeşitli sosyal ve kültürel özellikleri de yansıttığını ortaya koymuştur.
\end{abstract}

Anahtar Sözcükler: Teşekkür bölümü, teşekkür etme, doktora tezleri, akademik söylem, sosyopragmatik varyasyon 


\section{Introduction}

Given its importance in scholarly practices, the organizational patterns of an academically valued piece of writing have gained increasing attention in the academic discourse community. There is now a large volume of studies in English investigating the patterns utilized in specific parts of primary genres such as research articles, journal and conference abstracts, review articles, dissertations and other academic texts (Swales, 1996). Besides their prevailing academic conventions, a very important consideration in producing such types of written texts is that language does not exist in isolation, but is an interactional phenomenon used for social purposes. Hyland (2004) underlines this fact by stating that academic genres "are not purely informational but often rely on accomplishing audience-sensitive tone for their success" ( $p$. 303). One genre type whereby writers have the opportunity to reflect both their scholarly and socio-cultural identity and that has received scant interest within the research agenda is dissertation acknowledgement.

Despite their non-obligatory status, doctor of philosophy dissertation acknowledgements (henceforth PhDAs) are becoming more pervasive. As Cronin (1995) notes, "the voluntary nature of acknowledgement is de facto evidence of its perceived usefulness within this discourse community" (p.81). Such pervasiveness signifies that the function of this interstitial genre extends beyond merely providing a list of gratitude (Swales, 2004). Thus, PDAs constitute the intertwining of the intricacies involved in scholarly communication and tactical choices made by post-graduate students. The rhetorical complexity of this undertaking and motivational factors behind their construction make acknowledgements the objective of further studies to be conducted by genre analysts and practitioners who are interested in English for Specific Purposes (ESP). Such scholarly investigations carried out within the field of ESP might stem from practical needs since it could be useful to present researchers appropriate models of academic texts (Bhatia, 1993; Toprak, 2011).

Several studies have shed light on the rhetorical structure of acknowledgements in academic texts, particularly the ones taken from theses and dissertation as well as the patterns and communicative functions of conveying gratitude in these types of texts (e.g., Al-Ali, 2010; Hyland, 2003, 2004; Hyland \& Tse, 2004; Giannoni, 2002; Nguyen, 2017). However, to the best knowledge of the researchers, far too little attention has been paid to understand the generic 
structure of $\mathrm{PhD}$ dissertation acknowledgements in particular in the Turkish context. Hence, the present study intends to contribute to this line of research, a scholarly endeavour that has been called for by a number of researchers in the field of genre analysis (e.g., Hyland, 20003, 2004; Giannoni, 2002; Al-Ali, 2010; Nguyen, 2017). To this end, in the light of the contentbased framework proposed by Hyland and Tse (2004), the main objective of this research is to explore the rhetorical choices and possible socio-pragmatic motives appearing in the acknowledgement sections of dissertations based on an English corpus of $136 \mathrm{PhD}$ dissertations written by native speakers of American English and Turkish in three fields (i.e., Linguistics, Applied Linguistics and English Language Teaching).

In this regard, the present study aims to compare and contrast the rhetorical organization of acknowledgements accompanying $\mathrm{PhD}$ dissertations written in English by post-graduate native speakers of English and Turkish. In this study, we pose a comparative approach to the analysis of the corpora not only to investigate the lexico-grammatical elements used for the expression of gratitude in $\mathrm{PhDAs}$ but also to understand the underlying socio-pragmatic proclivities that could vary across both corpora.

\section{Literature Review}

\section{Previous Studies on Dissertation Acknowledgements}

As emphasised by Jordan (1997), the significance of maintaining a formal style lies at the heart of academic writing. This manifests itself at a number of stages such as a stylistic shift to a more formal tone, the choice of vocabulary items, personal pronouns and construction of sentence structures. With its distinctive features, one specific part of scholarly writing, that is, acknowledgements reflect not only certain academic writing conventions but also a socioculturally significant repertoire of authors. Given the pervasiveness of acknowledgements especially in dissertations, it is possible to note that their communicative functions as well as textual construction continue to constitute the focus of genre studies.

The majority of studies on acknowledgements in dissertations make reference to the ones conducted by Hyland (2003, 2004) and Hyland and Tse (2004), which aimed to explore the social and cultural elements represented by the expressions of gratitude and rhetorical roles of 
acknowledgement sections. The researchers analysed 240 Master's theses and $\mathrm{PhD}$ dissertations written by non-native speakers of English in six academic disciplines and interviewed postgraduate writers. Both the quantitative and qualitative findings unravelled not only the regular patterns by means of which acknowledgements were textualized but also how masters and doctoral students utilized this type of genre to project a professional stance and disciplinary allegiance.

In another study, Afful and Mwinlaaru (2010) investigated how multiple identities can be enacted through the linguistic choices used in an MA thesis which was written at a public university in Ghana. Similar to Hyland (2003, 2004), Afful and Mwinlaaru (2010) followed a rhetoric move analysis. The results of the study identified two moves, namely gratitude to various people and reflecting on the support provided by them. It was also revealed that while constructing his identities (e.g., academic, social and personal), the postgraduate student recurrently made use of linguistic resources at several layers including lexis, grammar and discourse. Differing relationships with the acknowledged ones were found to be reflected by a hybrid discourse which entailed a combination of formal, semi-formal and informal features. Cheng (2012), on the other hand, set out to explore the thanking patterns which appeared in Master's acknowledgements written in English by Taiwanese and North American students. The researcher concluded that norms of the academic discourse community to which the student writers belonged, and socio-cultural values led to variation in the use of thanking patterns, lexical realization and the order in which the addressees were thanked. It was also highlighted that the position of addresses had an influence upon the choice of gratitude expressions. Likewise, Mohammadi (2013) analysed 80 Persian and 80 English PDAs written by the native speakers of Persian and native speakers English respectively. The two data sets were examined within the framework of the three-tier structure proposed by Hyland (2004), namely the Reflective - Thanking - Announcing Move structure. One additional move, that is, "Thanking God" was reported in $80 \%$ of the Persian PDAs and $4 \%$ of the English corpus. As Devitt (2004) notes, the emergence of this new move suggests that genres are inclined to contextual changes and uses of a given language.

Another contrastive study in literature was conducted by Afip, Ustati and Dahan (2013), who aimed to explore the structure of acknowledgements written in Malay and Chinese as well as the linguistic elements employed in performing the act of gratitude in post-graduate theses. To 
this end, the researchers reviewed 40 acknowledgements written by Malay and Chinese MA students. The findings of the study revealed that Hyland's three-tier generic structure of expressing gratitude was observed in both corpora. However, differences were still identified. When compared to the Malay corpora, the acknowledgement sections accompanying the Chinese post-graduate theses were observed to contain a higher number of adjectives and adverbs in conveying their debt of gratitude for academic assistance and resources. Moreover, the sub-move of divine appreciation (i.e., Thanking God) was included in 55\% of Malay acknowledgers. This result was in support of Al-Ali (2010) and Mohammadi (2013) in that both studies refer to the influence of religious orientation on gratitude expressions realised by mentioning the word Allah (God).

In the context of the current study, thesis and dissertation acknowledgements have been addressed merely by Karakaş (2010). On analysing 144 acknowledgement sections written in English by the native speakers of Turkish (NST; N=72) and the native speakers of American English (NSAE; N=72), respectively, Karakaş (2010) found out that hedging and formal forms of thanking were more frequently employed in the Turkish corpus. Furthermore, it was observed that the NSAE tended to give more place to reflect on their own research experience when compared to the NST, who refrained from utilizing a self-enhancement communication style.

\section{Method}

\section{The Corpus}

The corpus used in the present study consisted of $136 \mathrm{PhD}$ dissertation acknowledgements written by English-speaking authors and Turkish authors in English. 77 acknowledgements belonged to English-speaking authors while the number of acknowledgements written by Turkish authors was 59. These acknowledgements were taken from the $\mathrm{PhD}$ dissertations written in the fields of Applied Linguistics and English Language Teaching between the years of 2000-2015 with the intention of creating a more homogenous pool of $\mathrm{PhD}$ acknowledgements that covers a substantial period of time rather than targeting a limited time span. The dissertations were drawn from two different databases by using keywords such as "applied linguistics", "English language teaching”, and "English language education”. English- 
speaking authors' dissertations were drawn from ProQuest's dissertation database. These keywords were selected on purpose to limit the scope of the research to the studies conducted within the fields of applied linguistics, language education and English language teaching. The corpus was restricted to dissertations completed at US-based universities to render the analyses more manageable. On the other hand, Turkish authors' acknowledgements were retrieved from the Turkish Higher Education Council's dissertation database which can be accessed via https://tez.yok.gov.tr/UlusalTezMerkezi/giris.jsp. These dissertations were completed at the Turkish universities. For the sake of consistency, the terms American acknowledgements and Turkish acknowledgements are used throughout the article to refer to the two corpora (US based English-speaking authors' dissertations and Turkish authors' dissertations) used for the analysis.

\section{Data Analysis}

Data analysis was conducted by using the move analysis technique. Move analysis can be defined as an approach to discourse analysis utilised in the research and teaching of genres and is rooted in Swales' genre theory, which concentrates on communicative purposes referred to as moves and steps (Cotos, 2018). Dudley-Evans and St. John (1998, p. 89) present a concise definition of a move and a step when they put forward "a move is a unit that relates both to writer's purpose and to the content that she/he wishes to communicate. A step, on the other hand, is a lower-level text unit than the move, providing a detailed perspective on the options open to the writer in setting out the moves." As can be understood from the definition, a move is a functional unit that is pertinent to the purpose of the writer to fulfil her/his communicative purposes within a text. In this study, these two-layered units of analysis were employed to examine the organizational structure of the acknowledgments. Each acknowledgement was examined repeatedly by the two researchers and a segment of an acknowledgement whose communicative function could not be determined was noted down to be examined and discussed later. To conduct the analyses, linguistics elements such as lexical items and discourse markers were also paid specific attention in addition to grasping general purpose and propositional meaning of the segments. There were cases in which a segment fulfilled more than one communicative function. In such cases, the most salient purpose of the segment was identified. 
The analyses were conducted based on the taxonomy developed by Hyland and Tse (2004) (See Table 1). Initially, a pilot study was conducted on 30 acknowledgements (15 American and 15 Turkish acknowledgements) to test whether the taxonomy of interest functioned effectively. After it was decided that the taxonomy functioned effectively, the rest of the corpus was analysed using a slightly modified version of Hyland and Tse (2004) (See Table 1). A significant modification was the inclusion of another step in the taxonomy, both for American and Turkish acknowledgements. Table 1 presents the taxonomy at the move and step level used for conducting analysis along with exemplar extracts taken from the English and Turkish corpus. Note that the asterisks indicate the steps that were originally not included in Hyland and Tse (2004) but were later added to the modified version based on our pilot analysis. Moreover, personal names mentioned in these segments have been masked in order to ensure confidentiality and privacy. The abbreviations TC and AC, used throughout the paper, refer to the "Turkish Corpus" and "American Corpus", respectively. Each dissertation is given a number; thus, for instance, TC-48 refers to the dissertation numbered 48 in the Turkish corpus. 
Table 1

Move Structure of The PhD Dissertations (Hyland \& Tse, 2004)

Moves/Steps Explanation Examples

1. Reflecting Move This move is used to offer insights into the author's research and dissertation writing experience and process.

1. "The writing of this dissertation has been the most significant challenge I have had so far in my academic career." (TC-48).

1. "Writing this dissertation has been a long and oft times isolating endeavor, yet my entire doctoral journey was one that I did not make on my own, nor could I have. This experience of pursuing a doctorate is one of paradox. It is a strange feeling to spend so much time in isolated thought knowing that the outcome is dependent only on my work and yet to know at the same time that just outside of the thought world is an entire community supporting me. It has been a very humbling and at the same time emboldening experience." (AC-6)

2. Thanking Move

2.1.Presenting participants, introducing those to be thanked

2.2. Thanking for academic assistance

2.3. Thanking for resources

2.4. Thanking for moral support

2.5.a. Thanking everyone*

(TC)/

2.5.b. Thanking God (EC)*

3. Announcing Move

3.1. Accepting

responsibility

3.2. Dedicating thesis to an

individual

\section{This move is used to} map credit to

individuals and institutions.

2.1. "This work would not exist without the help of a great number of great people. I am grateful to my students, teachers, and colleagues for partnering with me along the way." (AC-49).

2.2. "First and foremost I would like to thank [name], my dissertation advisor, who has guided me almost from the outset of this research project. Her knowledge of statistics and research methodology, coupled with her work ethic ensured that the project was able to keep momentum, and also always headed in the right direction. She has taught me so much as a researcher, particularly with the use of Hierarchical Linear Modeling, and I really feel that having worked closely with her for several years has enabled me to grow and develop professionally. I believe that the things she has taught me will help me for the rest of my career in this field." (AC-42)

2.3. "Lastly, I am grateful to various institutions for their financial and academic support to me during my PhD journey. TUBITAK (The Scientific and Technological Research Council of Turkey) supported me with its scholarship programs 2211-A (Graduate Scholarship Programme), 2224 (International Winter School) and 2214-A (International Research Fellowship Programme). I wish to thank the TUBITAK for its support of this research and all the support to me. In addition, I thank the U.S. Embassy English Language Office (ELO) for giving me invaluable online e-learning experiences and The National Agency (UA) for giving me a teaching experience in England. All institutions gave me chance of increasing my academic and pedagogical subject-knowledge." (TC-40).

2.4. "Last but not least, I would like to express my whole hearted feelings to my family. I am especially indebted to my son [name] whose presence has been the reason for my enthusiasm for life and has been a moral support throughout the dissertation process. I am also grateful to my husband, [name], for sharing my highs and lows through his love and patience, and for his endless support throughout this study." (TC-46)

2.5.a. "Therefore, I wish to extend my thanks to all who contributed to this study no matter how little. Thank you all..."( TC-25).

2.5.b. "I would like to give glory and honor to my Lord and Savior for gracing me with the physical, emotionally and spiritual strength to persevere and complete this research project." (ACA-7)

This move is used to 3.1. I confirm that it is me myself who is responsible for the inconveniences and shortcomings of this dissertation, if any. (TC-13).

make statements to

delineate

3.2. "And last, but certainly not least, I wish to thank my dear wife, [name], without whose love, patience, and support I might never have started down this road to begin with. Her years as my loyal life partner have provided me with the constant encouragement I needed at the most difficult moments and have helped me find the determination required to finish. This dissertation is dedicated to her." (AC-47). 


\section{Results}

This section presents results about the move structure patterns and move/steps found in Turkish and American acknowledgements.

\section{Move Patterns}

Below, Table 2 displays the results of the analysis conducted to detect the move patterns in Turkish and American acknowledgements. Five distinct move patterns were detected in the Turkish corpus. The majority of the acknowledgements (68\%) consisted of only M2, Thanking move. The second frequently used move pattern was M1+M2 (17\%), in which authors used Reflecting and Thanking moves consecutively.

Table 2

Move Patterns in the Turkish PhD Acknowledgements

\begin{tabular}{lll}
\hline Move pattern & Frequency & Percentage \\
\hline M2 (Thanking) & 40 & $68 \%$ \\
M1+M2 (Reflecting + Thanking) & 8 & $17 \%$ \\
M2+M1+M2 (Thanking + Reflecting + Announcing) & 5 & $8 \%$ \\
M2+M3 (Thanking + Announcing) & 3 & $4 \%$ \\
M1+M2+M3 (Reflecting + Thanking + Announcing) & 2 & $3 \%$ \\
TOTAL & 58 & 100 \\
\hline
\end{tabular}

Results pertaining to the American acknowledgements are presented in Table 3. Eight different move patterns were detected in the American acknowledgements, which exhibited more variety than the Turkish acknowledgements. 
Table 3

Move Patterns in the American PhD Acknowledgements

\begin{tabular}{lll}
\hline Move pattern & Frequency & Percentage \\
\hline M2 (Thanking) & 47 & $63 \%$ \\
M1+M2 (Reflecting + Thanking) & 11 & $15 \%$ \\
M2+M3 (Thanking + Announcing) & 5 & $7 \%$ \\
M2+M1 (Thanking + Reflecting) & 5 & $7 \%$ \\
M1+M2+M1 (Reflecting + Thanking + Announcing) & 3 & $4 \%$ \\
M2+M3+M2 (Thanking + Announcing + Thanking) & 2 & $2 \%$ \\
M3+M2+M1+M2+M3+M2 (Announcing + Thanking + Reflecting + & 1 & $1 \%$ \\
Thanking + Announcing + Thanking) & 1 & $1 \%$ \\
M1+M2+M3+M2 (Reflecting + Thanking + Announcing + Thanking) & 1 & $100 \%$ \\
\hline TOTAL & 75 & \\
\hline
\end{tabular}

Similar to the case observed in the Turkish acknowledgements, the majority of the American acknowledgements consisted of M2, Thanking (63\%). The second frequently used move pattern was M1+M2 (15\%), followed by M2+M3 (\%7) and M2+M1 (\%7). When compared to the Turkish acknowledgements, American acknowledgements also exhibited a greater degree of cyclicity in terms of move patterns, a situation which is reflected in $\mathrm{M} 1+\mathrm{M} 2+\mathrm{M} 1(4 \%)$, $\mathrm{M} 2+\mathrm{M} 3+\mathrm{M} 2(2 \%), \mathrm{M} 3+\mathrm{M} 2+\mathrm{M} 1+\mathrm{M} 2+\mathrm{M} 3+\mathrm{M} 2(1 \%)$ and $\mathrm{M} 1+\mathrm{M} 2+\mathrm{M} 3+\mathrm{M} 2(1 \%)$.

\section{Frequency of Moves and Steps}

Overall, the number of step structures used in the Turkish acknowledgements was 372, including the frequency of M1, which did not include any steps. On average, six different steps were used per acknowledgement. Below, Table 4 presents the frequency of these structures and their corresponding percentages. 
Table 4

Moves and Steps in the Turkish PhD Acknowledgements

\begin{tabular}{lll}
\hline Label & Frequency & Percentage \\
\hline M2S2 (Thanking for academic assistance) & 124 & $33 \%$ \\
M2S4 (Thanking for moral support) & 115 & $31 \%$ \\
M2S3 (Thanking for resources) & 74 & $20 \%$ \\
M2S1 (Introducing those to be thanked) & 26 & $7 \%$ \\
M2S5 (Thanking everyone) & 14 & $4 \%$ \\
M1 (Reflecting) & 14 & $4 \%$ \\
M3S2 (Dedicating thesis to an individual) & 5 & $1 \%$ \\
M3S1 (Accepting responsibility) & 1 & Less than $1 \%$ \\
TOTAL & 373 & $100 \%$ \\
\hline
\end{tabular}

As Table 4 reveals, the most frequently used step was M2S2, thanking for academic assistance occurring 124 times (33\%), followed by M2S4 thanking for moral support occurring 115 times (31\%) and M2S3 thanking for resources occurring 74 times (20\%). One interesting communicative function expressed in the Turkish acknowledgements was M2S5, thanking everyone, which was used to express thanks to everyone involved without mentioning any specific parties being thanked, or indicating the motivation behind thanking. This function was not detected in the American acknowledgements but was frequently used in the Turkish acknowledgements, generally as a wrap-up at the end of the acknowledgements.

Regarding the American acknowledgements, the number of step structures used in these sections was 341, including the frequency of M1, which did not include any steps. On average, five different steps were used per acknowledgement. Below, Table 5 presents the frequency of these structures and their corresponding percentages. 
Table 5

Moves and Steps in the American PhD Acknowledgements

\begin{tabular}{lll}
\hline Label & Frequency & Percentage \\
\hline M2S2 (Thanking for academic assistance) & 101 & $30 \%$ \\
M2S4 (Thanking for moral support) & 93 & $27 \%$ \\
M2S3 (Thanking for resources) & 64 & $19 \%$ \\
M2S1 (Introducing those to be thanked) & 38 & $11 \%$ \\
M1 (Reflecting) & 25 & $7 \%$ \\
M2S5 (Thanking everyone) & 9 & $3 \%$ \\
M3S1 (Accepting responsibility) & 6 & $2 \%$ \\
M3S2 (Dedicating thesis to an individual) & 5 & $1 \%$ \\
TOTAL & 341 & 100 \\
\hline
\end{tabular}

Although the number of their occurrences was higher in the Turkish acknowledgements, M2S2 thanking for academic assistance (30\%), M2S4 thanking for moral support (27\%) and M2S3 thanking for resources (17\%) were also the most frequently used steps in the American acknowledgements, used in 101, 93 and 64 instances respectively. One communicative function that was not detected in the Turkish acknowledgements but observed in the American acknowledgements was thanking God, labelled as M2S5. This step was used to express gratitude to God to thank him for the strength that he gave dissertation authors to complete their $\mathrm{PhD}$ journey. In a similar vein, the Turkish acknowledgements included an undetected step in the American corpus, "Thanking everyone", which was used to present thanks to individuals without giving specific details.

\section{Discussions and Conclusions}

The current study set out to unravel the component rhetorical structure of the $\mathrm{PhD}$ acknowledgements by English-speaking authors and Turkish authors in English. To this end, the macro-textual analysis of $136 \mathrm{PhD}$ dissertations were conducted in light of Hyland and Tse (2004) coding scheme by referring to the frequency of each move and step. Additionally, in 
order to discern the motive underlying the component moves which mirror the authors' communicative intentions, these moves, and lexico-grammatical choices were analysed from a socio-pragmatic perspective. The most frequent move across both corpora was Move 2 (Thanking) while the most frequent step M2S2 was (Thanking for academic assistance) followed by M2S4 (Thanking for moral support) and M2S3 (Thanking for resources).

The results reveal that while writing their PhDAs, both American English and Turkish authors tend to conform to the three-tier structure proposed by Hyland and Tse (2004) (i.e., Reflecting Move, Thanking Move and Announcing Move). Although the present corpus accommodates well with Hyland and Tse's (2004) model, a new step categorized under the Thanking Move was identified in acknowledgements written by Turkish authors, namely thanking everyone as in "Approximately 900 people contributed to this dissertation. I would like to thank all of them. (TC-49)". In another case, thanking everyone was used as:

\section{"Lastly, I offer my regards and blessings to all of those who supported me in any respect during the completion of this dissertation. (TC-1)" and "Thanks to everyone whose names I might have forgotten for their support, cooperation and help to make this study a reality. (TC-13)."}

The occurrence of this move merely in the Turkish acknowledgements may be rooted in Turkish culture where, as Zeyrek (2001, p. 48) points out, interpersonal relationships are supposed to be "close, intimate and warm enhancing supportiveness and generosity." As noted earlier, aside from functioning as a wrap up at the end of the acknowledgement section, this move helps acknowledgers to avoid rapport-neglecting orientation to anyone whom they have interacted thus far, which reverberates the viewpoint put forward by Zeyrek (2001). Based on the above-mentioned explanation, it can be argued that by thanking everyone, the authors tend to expand the scope of their gratitude in that it not only involves their professional identity but also relational identity. To put it differently, while writing the dissertation acknowledgement section texts, authors are inclined to position themselves within their professional communities who had provided feedback alongside intellectual and moral support. Furthermore, it is significant to stress that through this step the Turkish acknowledgers chose to express their appreciation to all the addressees and project self in relationship with others (i.e., their relational identity), which is meant to cover the whole spectrum of interpersonal interactions. 
The role of socio-cultural context should also be noted here since as rules of politeness and facework guiding interactions are established by social institutions (Fraser \& Nolen 1981), including religious institutions. To illustrate, the severity of the offence variable of Brown and Levinson's (1987) paradigm might be influenced by the interlocutor's culture, as what is seen as offensive in one society might be seen as appropriate behaviour in another. Hence, religious motivations in particular are expected to affect the formulation of gratitude expressions. Unlike the Turkish corpus, the analysis of the American PhDAs corroborate this argument through the step Thanking God as in:

"I would like to give glory and honor to my Lord and Savior for gracing me with the physical, emotionally and spiritual strength to persevere and complete this research project." (AC-7).

Although the word Allah (Turkish equivalent of the word God) and expressions that have a religious content are widely uttered on a daily basis for a great number of purposes, no reference to God was made in the Turkish acknowledgements.

An interesting finding is the fact that move cycling occurred in both sets of PhDAs. Cyclicity in move patterns has previously been detected in what are generally lengthy texts, for instance in $\mathrm{PhD}$ thesis introductions (Bunton, 2005) as well as results and discussion sections in dissertations (Hopkins \& Dudley-Evans, 1988). In light of the data analysis, it is worth noting that move cycling may not be confined to the aforementioned sections of academic texts. A likely explanation for the recurrence of cyclic patterns (e.g., M1+M2+M1, M2+M3+M2, $\mathrm{M} 3+\mathrm{M} 2+\mathrm{M} 1+\mathrm{M} 2+\mathrm{M} 3+\mathrm{M} 2$ and $\mathrm{M} 1+\mathrm{M} 2+\mathrm{M} 3+\mathrm{M} 2)$ in the present corpora suggests that the authors intend to convey the meaning of their acknowledgements and present their gratitude in a rhetorically effective way by adding more stylistic variations.

Another important finding was the lack of M3S1 (Acknowledging responsibility) in the American and more strikingly in the Turkish corpus. This step was used to delineate responsibility as in "Of course, any shortcomings or limitations in the study are my own. (AC15)". This step was used only once in the Turkish corpus, while it was used six times in the American corpus. The scarcity of this step which helps researchers to make statements to delineate responsibility for their research seems to be interesting. The lack of M3S1, "acknowledging responsibility" might have something to do with the need to protect the researcher's quality face (Spencer-Oatey, 2002), namely the value attributed to the researcher 
within the academic community. The authors can choose not to utilize "acknowledging responsibility" in their dissertation acknowledgements to avoid public loss of quality face in the academia and fulfil the "desire to be liked, approved of, respected, appreciated by others" (Thomas, 1995, p. 169).

Likewise, M3S2, dedicating thesis to an individual was found to be rather scarce, occurring only five times both in the Turkish and American corpus. This step featured a formal dedication of the thesis work to an individual or individuals as in:

"I dedicate this thesis to adult English language learners in the U.S. I hope that in some way my work contributes to increasing their English language skills and the betterment of their lives in the U.S. (AC-3)".

A further examination revealed that 31 out of 77 American dissertations featured a separate dedication page in which the authors bestowed a high honour on a person or a group of people, who on most occasions, were found to be family members. On the other hand, merely five out of 59 Turkish dissertations included a separate dedication page. The scarcity of this particular step in the American corpus can be attributed to the presence of a separate dedication page, on which the authors were able to express their friendly connections and thanks. However, this was not case in the Turkish corpus, since dedications were found to be highly limited both as a step and a separate section. This situation might have to do with the nature of dedications, which tend to be private and could have a special meaning for dedicators and dedicatees. The Turkish authors might have refrained from openly revealing private information about the people to which thesis work was dedicated.

Overall, the findings unravel that the acknowledgement section goes beyond being merely a part of a given dissertation. Thus, its construction mirrors "social and cultural characteristics" (Hyland, 2003, p. 242). Additionally, it appears that dissertation acknowledgements, which are laden with graduate students' humble, sincere, and warm-hearted proclamation, differ from book or research article acknowledgements in which academic credibility comes more to the forefront. In this study, the choice of thanking strategies as well as addresses and linguistic realizations features thesis acknowledgements as a socialized yet personally and emotionally engaged genre. 
Although previous research has revealed that thanking is a universal speech act used by speakers of different languages, the way this speech act is realised seems to differ considerably across speech communities due to cultural differences (e.g., Apte, 1974; Cheng, 2005; Eisenstein \& Bodman, 1986; Naito, Wangwan, \& Tani, 2005; Pishghadam, \& Zarei, 2012; Wang, 2011). In one of the earliest studies on the speech act of thanking, Apte (1974) found that there were considerable variations between American English gratitude expressions and South Asian gratitude expressions in Marathi and Hindi. While the American gave thanks for gifts, services and favours, the speakers of Marathi and Hindi offered their thanks to close friends and family members with whom they had special bonds. In another study by Wang (2011), while English speakers regarded everybody as equal and expressed their gratitude on each occasion they were helped, the Chinese mostly thanked people who helped them many times. In our case, the speakers of both languages thanked mostly for academic assistance, moral support, and resources. However, the findings also revealed that several American authors thanked God while some Turkish authors thanked everybody involved without mentioning a specific name. Moreover, the Turkish authors scarcely featured a dedication section in their dissertations and seemingly refrained from openly sharing private information about the people to which their dissertations were dedicated.

Insights elicited from the current study may also inform pedagogical decisions to provide postgraduate students with training in constructing acknowledgements. As an interactive text, the forms of thanking employed in the genre assume a significant role in the maintenance of the face of the addressee and the self. Thus, it is crucial that non-native speakers are trained in such contexts of thanking so that they can become more aware of the pragmatic functions of acknowledgements Additionally, as Hyland (2004) argues, since acknowledgements reflect authors' academic and social identity, teachers should train students in writing acknowledgements. Finally, it would be of interest for further research to compare acknowledgements in different contexts, such as the use of thanking strategies and their linguistic realizations in oral and written genres at both rhetorical and pragmatic interfaces.

\section{Statements of Ethics and Conflict of Interest}


"I, as the Corresponding Author, declare and undertake that in the study titled as " $A$ Contrastive Study on the Generic Structure and Socio-pragmatic Proclivities in Acknowledgements", scientific, ethical and citation rules were followed; Turkish Online Journal of Qualitative Inquiry Journal Editorial Board has no responsibility for all ethical violations to be encountered, that all responsibility belongs to the author/s and that this study has not been sent to any other academic publication platform for evaluation."

\section{References}

Afful, J., \& Mwinlaaru, I. (2010). The construction of multiple identities in the acknowledgement section of a master's dissertation. English for Specific Purposes World, 30(9), 1-26.

Afip, L. B. A., Ustati, M. K. H, \& Dahan, H. (2013). The differences between Malay and Chinese post-graduates' gratitude: The generic structure of dissertation acknowledgement. Researchers World: Journal of Arts, Science \& Commerce, 4(3), $1-10$

Al-Ali, M. N. (2010). Generic patterns and socio-cultural resources in acknowledgements accompanying Arabic PhD dissertations. Pragmatics, 20(1), 1-26.

Apte, M. L. (1974). “Thank you” and South Asian languages: A comparative sociolinguistic study. International Journal of the Sociology of Language, 3, 67-90.

Bhatia, V. K. (1993). Analyzing genre: Language use in professional settings. London: Longman.

Cheng, S. W. (2005). An exploratory cross-sectional study of interlanguage pragmatic development of expressions of gratitude by Chinese learners of English. Unpublished doctoral dissertation, University of Iowa.

Cheng, W. (2012). A contrastive study of master thesis acknowledgements by Taiwanese and North American students. Open Journal of Modern Linguistics, 2(1), 8-17.

Cotos, E. (2018). Move analysis in C.A. Chapelle (Ed.), Encyclopedia of applied linguistics. Oxford: Wiley-Blackwell.

Cronin, B. (1995). The scholar's courtesy: The role of acknowledgements in the primary communication process. London: Taylor Graham.

Devitt, A. J. (2004). Writing genres. Carbondale: Southern Illinois University Press. 
Eisenstein, M., \& Bodman, J. W. (1986). "I very appreciate": Expressions of gratitude by native and non-native speakers of American English. Applied Linguistics, 7(2),167185.

Giannoni, D. S. (2002). Words of gratitude: A contrastive study of acknowledgement texts in English and Italian research articles. Applied Linguistics, 23(1), 1-31.

Hyland, K. (2003). Dissertation acknowledgements: The anatomy of a Cinderella genre. Written Communication, 20, 242-268.

Hyland, K. (2004). Graduates' gratitude: The generic structure of dissertation acknowledgements. English for Specific Purposes, 23, 303-324.

Hyland, K., \& Tse, P. (2004). "I would like to thank my supervisor": Acknowledgements in graduate dissertations. International Journal of Applied Linguistics, 14(2), 259-275.

Jordan, R. R. (1997). English for academic purposes. Cambridge: Cambridge University Press. Karakaş, Ö. (2010). A cross-cultural study on dissertation acknowledgments written in English by native speakers of Turkish and American English. Unpublished master's thesis. Middle East Technical University, Ankara, Turkey.

Mohammadi, M. J. (2013). Do Persian and English dissertation acknowledgments accomodate Hyland's model: A cross-linguistic study. International Journal of Academic Research in Business and Social Sciences, 3(5), 534-547.

Naito, T., Wangwan, J., \& Tani, M. (2005). Gratitude in university students in Japan and Thailand. Journal of Cross-Cultural Psychology, 36(2), 247-263.

Nguyen, T. T. L. (2017). Generic structures and linguistic features of TESOL master's thesis acknowledgements written by Vietnamese postgraduates. The Southeast Asian Journal of English Language Studies, 23(2), 27-40.

Pishghadam, R., \& Zarei, S. (2012). Cross-cultural comparison of gratitude expressions in Persian, Chinese and American English. English Language Teaching, 5(1), 117-126.

Swales, J. M. (1996). Occluded genres in the academy: The case of the submission letter in E. Ventola \& A. Mauranen (Eds.), Academic Writing: Intercultural and Textual Issues, (pp. 45-58). Amsterdam: John Benjamins.

Swales, J. M. (2004). Research genres: Exploration and applications. Cambridge: Cambridge University Press.

Toprak, T. E. (2011). The textual organization of discussion and conclusions sections of research articles in applied linguistics. Unpublished master's thesis. Uludag University, Bursa, Turkey. 
Tuğba Elif Toprak Yıldız, Yasemin Aksoyalp

Wang, J. (2011). Cultural differences and English teaching. English Language Teaching, 4(2), 223-230. 